\section{Д.Л. Шереметьева*}

\section{Рынок товаров Новониколаевска в условиях Гражданской войны (конец мая 1918 - середина декабря 1919 года) ${ }^{* *}$}

doi:10.31518/2618-9100-2021-5-16

УДК 338(47)“1918/1919”

Выходные данные для цитирования:

Шереметьева Д.Л. Рынок товаров Новониколаевска в условиях Гражданской войны (конец мая 1918 - середина декабря 1919 года) // Исторический курьер. 2021. № 5 (19). С. 191-202. URL: http://istkurier.ru/data/2021/ISTKURIER-2021-516.pdf
D.L. Sheremeteva*

\section{Novonikolaevsk Goods Market During the Civil War (Late May 1918 - Mid-December 1919)**}

doi:10.31518/2618-9100-2021-5-16

How to cite:

Sheremeteva D.L. Novonikolaevsk Goods Market during the Civil War (Late May 1918 - MidDecember 1919) // Historical Courier, 2021, No. 5 (19), pp. 191-202. [Available online: http:// istkurier.ru/data/2021/ISTKURIER-2021-5-16.pdf]

Abstract. The article analyzes the dynamics of commodity-money relations in the key trade and transport hub of Western Siberia - the city of Novonikolayevsk, which from the end of May 1918 to the middle of December 1919 was one of the largest strongholds of the counterrevolution in the east of Russia. On the basis of a wide range of sources, changes in political and economic conditions, the spectrum of trade subjects, the range of goods, demand and prices were studied. As a result, it was found that the dynamics of the Novonikolayevsk commodity market during the Civil War followed a complicated trajectory. The market reacted to the overthrow of the Soviet government at the end of May 1918 with a rapid restoration of the trade sphere. Then, as the territory controlled by the anti-Bolshevik governments, supporting free trade, expanded, the number of sellers increased on the Novonikolayevsk commodity market, the range of goods and the demand for them grew. The extensive development of the Novonikolayevsk market was mainly due to the small private food trade, the reorientation of large commodity and monetary operations to the Ural, Far East and foreign markets, as well as the almost twofold growth of the population of the city. In the spring of 1919, the conditions for conducting trade began to deteriorate. The state power, providing for the increased military needs and trying to mitigate the economic losses of the population, began to interfere in market relations. Since March, the market in Novonikolayevsk functioned in a mode of adaptation to the increased pressure of the military department and the impact of monetary reform. The number of subjects of trade became excessive, in the assortment of goods the disproportions between the wide supply of food and the shortage of industrial products increased. The relatively smooth growth of prices was replaced by their abrupt dynamics. The retreat of the Russian government's armed forces from the Urals caused a short-term effect on the Novonikolayevsk market in the form of saturation with goods and a decrease in the cost of food in August, but then commodity-money relations began to lose the remnants of the proportion between supply and demand. Front-line conditions of the second half of November - the first half of December 1919 hampered trade further, which began to be reduced to small-scale forms.

Keywords: economy; trade; prices; Novonikolaevsk; Civil war.

The article has been received by the editor on 17.06.2021.

Full text of the article in Russian and references in English are available below.

\footnotetext{
* Шереметьева Дарья Леонидовна, кандидат исторических наук, Институт истории Сибирского отделения Российской академии наук, Новосибирск, Россия, e-mail: dalas83@yandex.ru

Sheremeteva Daria Leonidovna, Candidate of Historical Science, Institute of History of the Siberian Branch of the Russian Academy of Sciences, Novosibirsk, Russian, e-mail: dalas83@yandex.ru

** Исследование выполнено при финансовой поддержке РФФИ и Правительства Новосибирской области в рамках научного проекта № 20-49-540006.

The research was funded by RFBR and the Novosibirsk region, project number 20-49-540006.
} 
Аннотация. В статье проанализирована динамика товарно-денежных отношений в ключевом торгово-транспортном узле Западной Сибири городе Новониколаевске, - который с конца мая 1918 до середины декабря 1919 г. являлся одним из крупнейших опорных пунктов контрреволюции на востоке России. На основе широкого круга источников изучены изменения политико-экономических условий, спектра субъектов торговли, ассортимента товаров, спроса и цен. В результате установлено, что динамика товарного рынка Новониколаевска на протяжении Гражданской войны прошла сложную траекторию. На свержение советской власти в конце мая 1918 г. рынок отреагировал стремительным восстановлением торговой сферы. Затем по мере расширения территории, подконтрольной антибольшевистским правительствам, поддерживавшим свободу торговли, на новониколаевском товарном рынке увеличивалось количество продавцов, рос ассортимент товаров и спрос на них. Экстенсивное развитие новониколаевского рынка происходило в основном за счет мелкой частной торговли продовольствием, переориентации крупных товарно-денежных операций на уральский, дальневосточный и зарубежные рынки, а также за счет почти двукратного роста населения города. Весной 1919 г. условия для ведения торговли начали ухудшаться. Государственная власть, обеспечивая возраставшие военные нужды и пытаясь смягчать экономические потери населения, стала вмешиваться в рыночные отношения. С марта рынок в Новониколаевске функционировал в режиме адаптации к возраставшему давлению военного ведомства и удару денежной реформы. Количество субъектов торговли стало избыточным, в ассортименте товаров нарастали диспропорции между широким предложением продовольствия и дефицитом промышленных изделий. Относительно плавный рост цен сменился их скачкообразной динамикой. Отступление вооруженных сил Российского правительства с Урала принесло рынку Новониколаевска кратковременный эффект в виде насыщения товарами и снижения стоимости продовольствия в августе, но затем товарно-денежные отношения стали терять остатки пропорции между спросом и предложением. Фронтовые условия второй половины ноября - первой половины декабря 1919 г. еще больше стеснили торговлю, которая стала схлопываться до мелкотоварных форм.

Ключевые слова: экономика; торговля; цены; Новониколаевск; Гражданская война.

Новониколаевск возник и первые полтора десятилетия XX в. стремительно развивался во многом благодаря своей уникальной роли. Он почти изначально являлся ключевым торговотранспортным узлом Западной Сибири, соединявшим сельхозпроизводящие районы с рынками сбыта и источниками промышленных товаров. Во время Первой мировой и Гражданской войн увеличилась административно-политическая и военная роль города. На полтора года, с конца мая 1918 до середины декабря 1919 г., Новониколаевск стал одним из крупнейших опорных пунктов контрреволюции на востоке России. Сложнее оценить экономическое значение Новониколаевска в это время, хотя экономике Сибири периода Гражданской войны посвящена обширная научная литература. Однако в современной историографии рынок Новониколаевска представлен очень однобоко и даже тенденциозно, изображен лишь в виде площадки анархии и спекуляции ${ }^{1}$. Одной из причин такой трактовки является, по всей вероятности, состояние источниковой базы.

Ключевой информацией о состоянии рынка должны были обладать органы самоуправления, т.к. как городская управа выдавала разрешения на торговлю, регистрировала торговые предприятия, сдавала в аренду базарные места, собирала налоги и пошлины, следила за обеспеченностью населения товарами и услугами первой необходимости. Однако статистический отдел Новониколаевской городской управы функционировал с перебоями и

\footnotetext{
${ }^{1}$ См.: Черных Г.И. Торговля в Новосибирске // Новосибирск. Энциклопедия. Новосибирск:, 2003. С. 879-880; Косякова Е.И. Из истории городской повседневности Новониколаевска-Новосибирска (1893-1941 гг.): роль поставок продовольствия из окрестных деревень в питании горожан // Труды Новосибирского государственного аграрного университета. Экономика. Проблемы сельского хозяйства России. Новосибирск, 2004. С. 246-259; Кокоулин В.Г. Повседневная жизнь горожан Сибири в военно-революционные годы. Новосибирск, 2013; и др.
} 
документы справочного характера составлял не систематически. Например, полный список выданных торговых свидетельств сохранился только за 1917 г., раскладка трактирных промыслов - за 1918 г., единственный перечень необходимых предметов снабжения для горожан датирован январем 1919 г. Бюллетени рыночных цен статистический отдел составлял чаще, но сохранились лишь отдельные сводки за летние месяцы 1919 г.

Отсутствие полноценной муниципальной статистики отчасти восполняют источники ведомственного и кооперативного происхождения. Информацию о ценах на продовольственные товары первой необходимости собирала Новониколаевская инспекция труда ${ }^{2}$. Ее специальная комиссия, в которую входили представители государственной власти, самоуправления, торгово-промышленников и кооперации, ежемесячно с июля 1918 г. по сентябрь 1919 г. считала величину прожиточного минимума на основе комплекса сведений о розничных ценах на базаре, в кооперативных и городских продовольственных лавках. Цены на товары первой необходимости также тщательно отслеживало информационное бюро крупнейшего кооперативного объединения Сибири - Союза сибирских кооперативных союзов (Закупсбыта), и с декабря 1918 по декабрь 1919 г. регулярно публиковало «Бюллетени рыночных цен».

Кроме того, ценным источником о состоянии рынка являются издававшиеся в Новониколаевске частные ежедневные общественно-политические и экономические газеты «Народная Сибирь», «Родная Сибирь» и «Русская речь». Пресса содержит объявления, рекламу, хроникерские заметки, отчеты торговых организаций, статьи на экономические темы и обзоры рынка. В общем имеются разнообразные по происхождению, информативности и достоверности источники. В комплексе они дополняют друг друга и, несмотря на лакуны, позволяют получить сведения о динамике товарного рынка Новониколаевска.

Широкомасштабная Гражданская война в России началась с восстания Чехословацкого корпуса и выступления отрядов Временного Сибирского правительства (ВСП) в Новониколаевске в ночь на 26 мая 1918 г. Советская власть в городе была стремительно свергнута. За военно-политическими действиями сразу последовали экономические мероприятия новой власти. 28 мая 1918 г. Новониколаевская уездная продовольственная управа объявила населению о свободе торговли, отменив монополии и твердые цены на пшеницу, муку, овес, крупы, масло, сыр и яйца. Уполномоченный ВСП по продовольственным делам 9 июня 1918 г. официально подтвердил отмену государственных монополий и твердых цен на рыбу, яйца, сыр и картофель. При этом продовольственный отдел Западно-Сибирского комиссариата ВСП придерживался регламентации в области хлеботорговли, маслозаготовок, кожевенной промышленности, а также сохранял запрет на продажу спиртных напитков и ряд других ограничений ${ }^{3}$.

С установлением в Новониколаевске антибольшевистской власти городские базары быстро наполнились продовольственными товарами. При этом цены на муку, мясо и масло снизились. Предприниматели начали так бойко требовать документы на право торговли, что в городской управе не хватало соответствующих бланков. После переворота городскому самоуправлению были переданы большие запасы казенных товаров, и часть из них, в том числе дефицитные сахар, спички и табак, поступили в продажу в городских продовольственных лавках. Вскоре городская продовольственная комиссия начала возвращать владельцам товары, реквизированные ранее местными советскими органами. В ежедневной общественно-политической и экономической газете «Народная Сибирь» с первого номера публиковались частные объявления о продаже товаров и коммерческая реклама ${ }^{4}$.

\footnotetext{
${ }^{2}$ См.: Рынков В.М. Продовольственный рынок Сибири во второй половине 1918-1919 гг.: пространственные и отраслевые модели // Исторические вызовы и экономическое развитие России: мат-лы всерос. науч. конф. с междунар. Екатеринбург, 2019. С. 461-466.

3 Западно-Сибирский комиссариат Временного Сибирского правительства (26 мая - 30 июня 1918 г.): сб. доктов и мат-лов. Новосибирск, 2005. С. 91, 93, 202.

${ }^{4}$ Народная Сибирь. 1918. 31 мая, 19 и 28 июня.
} 
Есть основания полагать, что за месяц после антибольшевистского переворота торговая сфера Новониколаевска восстановилась в формах и масштабах, существовавших в городе до установления Советской власти. Основными субъектами рынка вновь стали частные предприниматели, кооперативные организации и органы самоуправления. Наибольшую активность проявляла мелкая частная торговля, не требовавшая больших организационных и финансовых издержек и быстро приносившая прибыль. Сложнее обстояло дело с крупной торговлей. Торговые товарищества и торговые дома возобновляли деятельность медленнее, а Новониколаевская товарная биржа, считавшаяся венцом городской рыночной самоорганизации, в 1918 г. не работала. Относительно уверенно на рынке чувствовала себя кооперация, выросшая на местных ресурсах в годы Первой мировой войны, имевшая финансовый капитал, собственное производство, склады и лавки. В Новониколаевске располагалась главная контора Закупсбыта. Городская продовольственная комиссия при городской думе, пользовавшаяся казенными товарами, стремилась влиять на рыночные цены. Летом 1918 г. она расширила сеть своих продовольственных лавок с 10 до 16 и по дешевым ценам распродавала в них имевшиеся товары.

Новониколаевский рынок в июне 1918 г. в целом удовлетворял базовый потребительский спрос. Продукты местного хозяйства - хлеб, мясо, рыба, молоко, масло, яйца, овощи, дрова, сено - всегда были на рынке. Нездоровый ажиотаж отмечали газетные репортеры только вокруг таких привозных товаров, как сахар, монпансье, мануфактура и нитки.

30 июня 1918 г. государственная власть на территории Сибири перешла к Совету министров ВСП. Совмин продолжил политику освобождения рынка от государственного регулирования, разрешив вольные цены на хлеб и мясо, а затем принял решение о продаже в городах спиртных напитков ${ }^{5}$. В этих условиях восстанавливались торговые связи внутри Сибири, рынок расширялся, количество и объемы торговых операций увеличивались. Однако Сибирь оставалась отрезана фронтами военных действий от европейской территории России и от Дальнего Востока. Из-за этого не осуществлялся вывоз сельхозпродукции и не наблюдался приток денежных знаков, доступных кредитов и промышленных товаров, которые могли бы открыть возможности для крупных торговых операций и выравнивания рынка.

Но даже в таких непростых политико-экономических условиях торговая сфера Новониколаевска внешне выглядела как динамично расширявшаяся. Правда, такое ее состояние оценивалось разными специалистами и обывателями по-разному. Так, эксперт Новониколаевского отделения Московского народного банка оценивал рост количества продавцов положительно. Но член правления Закупсбыта В.Г. Шишканов об этом же отзывался нелицеприятно: «Буквально все спекулируют, кто чем попало» ${ }^{6}$. Фельетонист «Народной Сибири» в свою очередь высмеивал городскую барахолку с тысячами продавцов, редким ассортиментом товаров и отсутствием покупателей, а хроникер подмечал, что мешочники «тащат всякую всячину» 7 .

В июле - сентябре 1918 г. на городских базарах в изобилии продавали хлеб, крупы, мясо, колбасы, рыбу, птицу, молоко, масло, сыр, овощи, ягоды, семечки, мед, орехи, листовой табак, овес, сено, дрова и другие сибирские продукты. Урожай был хороший, и цены на товары колебались незначительно. Из так называемых бакалейно-колониальных товаров в Новониколаевске продавали чай, кофе, какао, сахар, монпансье, рис, разнообразные ткани и галантерею. Стоила привозная продукция дорого и оставалась малодоступна большинству горожан. На барахолке активнее шла торговля всяким «тряпьем и рваньем», главными покупателями которого были деревенские жители ${ }^{8}$.

\footnotetext{
${ }_{5}^{5}$ Временное Сибирское правительство (26 мая - 3 ноября 1918 г.): сб. док-тов и мат-лов. Новосибирск, 2007. C. 133-135.

${ }^{6}$ Народная Сибирь. 1918. 11 июля.

${ }^{7}$ Там же. 13 и 21 июля.

${ }^{8}$ Там же. 31 июля.
} 
23 сентября 1918 г. антибольшевистские правительства востока России на Государственном совещании в Уфе образовали Временное Всероссийское правительство, юрисдикция которого распространилась на Урал, Сибирь и Дальний Восток. 18 ноября в результате государственного переворота верховная власть перешла к Российскому правительству во главе с адмиралом А.В. Колчаком. Экономическая политика контрреволюции не претерпела при этом резких изменений. Тенденция к дальнейшему расширению свободы торговли получила в конце 1918 г. новое выражение в отмене монополии на масло и утверждении свободы торговли хлебом и мясом ${ }^{9}$. Для Новониколаевска одним из следствий сворачивания государственного присутствия в рыночных отношениях стала самоликвидация городской продовольственной комиссии и прекращение выдачи продовольственных карточек населению.

Для экономики Сибири открылись возможности внутренней торговли с промышленными центрами Урала и внешней торговли через Дальний Восток. Однако налаживанию товарооборота препятствовали кризисы финансовой сферы и транспорта. Антибольшевистские правительства по объективным причинам не могли ввести единую денежную систему и осуществить достаточную эмиссию. На рынке «ходили» деньги разных видов и достоинств и денежные суррогаты ${ }^{10}$. Товаропотоки шли неравномерно, т.к. железные дороги были «забиты» перевозками для армии. Поэтому снижения дефицита промышленных товаров не предвиделось. «До сих пор мы жили за счет накоплений старых годов», - писал осведомленный кооператор 19 сентября в «Народной Сибири». Он утверждал, что «то, что осталось, является каплей в море по сравнению с потребностью», «нельзя надеяться, что скоро у нас будут мануфактура, железо, сахар и другие товары». К тому же положение усугубил топливный кризис, на скорое разрешение которого никто не надеялся.

Макрорегиональная обстановка в полной мере влияла на рынок Новониколаевска. Осенью 1918 г. с Дальнего Востока и Урала начали бессистемно поступать крупные партии отдельных продовольственных и мануфактурных товаров, галантереи, обуви, железа и машинного оборудования. Закупсбыту, например, удалось заготовить несколько сотен вагонов рыбы в Приморье. Благодаря этому новониколаевцы на долгое время оказались обеспечены дешевой амурской кетой. Новониколаевское отделение Сибирской компании доставило в город табак и пряности. Частные предприниматели завезли сарпинку - легкую клетчатую хлопчатобумажную ткань. Городская продовольственная комиссия в сентябре распродавала крупную партию американских резиновых галош, а в декабре - нитки. РусскоАзиатская компания, техническая контора Блюменштейнов и техническая контора Нефедова возобновили торговлю железоскобяными товарами, орудиями труда и оборудованием для сельхозпроизводства. Ассортимент магазинов расширялся готовой одеждой, модной обувью, канцелярскими товарами, мехами, игрушками, ювелирными изделиями и косметикой.

На рынке сохранялось изобилие продуктов местного производства, но все же ощущался недостаток привозных товаров. Новониколаевские предприниматели пытались отвечать на хронические дефициты. Во-первых, скупка и продажа подержанных вещей стала настолько выгодным делом, что переросла «мелкие» формы. Ей занялись магазины и даже торговые товарищества. Во-вторых, массовым стало производство заменителей для товаров, пропавших с рынка. Новоявленные примитивные паточные заводы перерабатывали картофель в темную кремообразную массу с содержанием сахаристых веществ, условно подходившую для изготовления кондитерских изделий. Вместо пеньковой сноповязальной веревки в продажу поступала конопляная. В неограниченных количествах продавцы начали

\footnotetext{
${ }^{9}$ Совет министров Российского правительства: журналы заседаний (18 ноября 1918 - 3 ноября 1920 г.): сб. доктов и мат-лов. Новосибирск, 2016. Т. 1. С. 33, 114.

${ }^{10}$ См.: Рынков В.M. Финансовая политика антибольшевистских правительств востока России (вторая половина 1918 - начало 1920 г.). Новосибирск, 2006.
} 
предлагать сомнительные заменители нефти, олеонафта, ваксы, зеленой краски и других химических продуктов ${ }^{11}$.

Несмотря на большое количество продавцов и широкий ассортимент товаров новониколаевский рынок осенью 1918 г. все меньше удовлетворял спрос населения. В значительной мере такое ухудшение было обусловлено тем, что в октябре 1918 г. в Новониколаевск прибыла масса эвакуированных из Поволжья, взятого Красной Армией. По сведениям уплотнительной комиссии, город принял около 50 тыс. человек. Вместе с увеличившимся военным гарнизоном население города составило к ноябрю около 190 тыс. человек, т.е. нагрузка на экономику возросла почти вдвое по сравнению с 1917 г., когда в Новониколаевске проживало около 100 тыс. человек ${ }^{12}$. Количество «новых потребителей» было не сопоставимо с размером вновь поступивших товаров и оборудования. Для сферы торговли это означало повышение спроса на товары первой необходимости. В то же время хозяйственно-экономическая сфера Новониколаевска испытала усиление запросов со стороны военного ведомства. Для того чтобы одеть и обуть гарнизон, в городе запретили свободную торговлю военным обмундированием, тканями военного образца, сапогами, полушубками и пимами и, более того, объявили скупку у населения годных шинелей, рубах, шаровар и сапог. Уполномоченный министерства снабжения по Новониколаевскому району официально предупредил население, что если добровольно сданных вещей окажется недостаточно, то будет объявлена реквизиция ${ }^{13}$.

Следовательно, с конца мая до конца декабря 1918 г. новониколаевский рынок функционировал в условиях свободы торговли, с ограничениями на отдельные группы и категории товаров. За это время в городе было зафиксировано 2462 торговых предприятия, что почти вдвое превосходило аналогичный показатель 1917 г. с 1266 торговыми предприятиями и было выше максимума 1916 г., составлявшего 1560 торговых предприятий. Расширение рынка произошло за счет мелочной торговли, разрешений на которую в 1918 г. было выдано 1294 штуки по сравнению с 319 штуками в 1917 г. Количество продавцов прибавилось в основном в сферах продовольственной, галантерейной и мануфактурной торговли ${ }^{14}$.

Во второй половине 1918 г. в Новониколаевске предлагался широкий ассортимент товаров. Их основные группы были представлены хлебо-зерновыми, мясными, молочными, рыбными, бакалейными, галантерейными, мануфактурными, кожевенными, шубными, шапко-картузными, железо-скобяными и строительными товарами, продукцией машиностроения, лошадьми, а также готовой одеждой и обувью, мылом, алкоголем, мебелью, посудой, ювелирными изделиями, электрическими, техническими, канцелярскими и аптекарскими товарами. Торговля потребительскими товарами преобладала над продажей средств производства ${ }^{15}$.

Источники позволяют проследить изменение стоимости минимальной продуктовой корзины в Новониколаевске с июля по декабрь 1918 г. В ее состав входили ржаная мука, пшеничная сеянка, просо, гречка, перловка и рис, говядина, рыба, колбаса, сало, сливочное масло, картофель, капуста, лук, молоко, яйца, соль, сахар, чай, перец-горошек и лавровый лист. В июле 1918 г. этот продовольственный набор стоил 140,6 руб., в августе - 138,7 руб., в сентябре - 143,9 руб., в октябре - 165,8 руб., в ноябре - 166,6 руб., в декабре - 154,3 руб. Общая амплитуда колебания находилась в пределах $20 \%{ }^{16}$.

\footnotetext{
${ }^{11}$ Народная Сибирь. 1918. 11 октября, 15 ноября; и др.

${ }^{12}$ Русская речь. 1918. 16 ноября.

13 Там же. 6 сентября, 20 октября, 26 ноября.

${ }^{14}$ Весь Новониколаевск. Адресно-справочная книга с краткой историей и планом города. 1924-1925 год. Новониколаевск, 1925. С. 43-44.

15 Там же.

${ }^{16}$ Величина прожиточного минимума состояла из скрупулезно подсчитанной стоимости продуктов питания и добавленных к ней условных 45 \% на жилище, одежду и культурные потребности. О прожиточном минимуме по городам Западной Сибири в 1918 г. см.: Сизов С.Г. Белая столица России: повседневная жизнь Омска (июнь 1918 - ноябрь 1919 г.). Омск, 2018. С. 41.
} 
Цены на конкретные продукты зависели от разных рыночных взаимосвязей. Стоимость муки и круп определяло экономическое поведение крестьян, традиционно поднимавших цены на эти продукты осенью. Например, пуд ржаной муки стоил в июле 16 руб., в октябре - 25 руб. и в декабре - снова 16 руб. Цены на пшеничную сеянку в те же месяцы составляли 28 руб., 36 руб. и 30 руб. Явления спекулятивного характера наблюдались в отношении торговли картофелем. Как самый урожайный продукт, выращивавшийся повсеместно, он обычно стоил дешево. Однако в 1918 г. из-за скупки картофеля предпринимателями для производства паточного сахарозаменителя его стоимость выросла с 4 руб. за пуд в июле до 12 руб. в ноябре, а к концу года установилась на уровне 8 руб. Колебания цен на привозные товары зависели от поставок и акцизов. Так, фунт рассыпного чая подорожал с 15 руб. в июле до 36 руб. в декабре. Фунт сахара, напротив, подешевел с 18 руб. до 14 руб. Стабильностью отличались только цены на мясо. Летом говядина подешевела с 71 до 64 руб. за пуд, и такая цена держалась до конца года. Стабильность была результатом успешных мясозаготовительных операций городского самоуправления в условиях государственной монополии на масло и низкой закупочной цены, приводившей к разорению маслохозяйств и массовому забою скота ${ }^{17}$.

Кроме сферы торговли продовольственными товарами, источники позволяют проследить изменение стоимости дров. Пристальное внимание к этому товару обусловливалось его крайней необходимостью в суровом сибирском климате. Погонная сажень березовых дров на новониколаевском базаре летом 1918 г. стоила от 72 до 100 руб. Эта цена считалась не выгодной. Летом дрова заготавливали мало, т.к. потребность в них была ниже, чем в другие времена года, а транспортировка стоила дорого. Покупатели ждали понижения цен в сезон заготовки дров, открывавшийся обычно с установлением санного пути примерно в конце ноября. Однако в ноябре 1918 г. стоимость березовых дров на новониколаевском рынке не упала, а поднялась до 200 руб., т.к. спрос на них оказался невероятно высоким изза провала промышленных заготовок угля. ${ }^{18}$

Из товаров широкого потребления, не относившихся к безусловно необходимым, в источниках четко зафиксированы цены только на газеты. Стоимость подписки и объявлений в «Народной Сибири», «Русской речи» и «Военных ведомостях» зачастую разнилась, но в розничной продаже газеты почти всегда шли по одинаковой цене. На протяжении июня декабря 1918 г. эта «выравнивающая» величина постепенно выросла с 30 до 40 коп., что было следствием хронического недостатка на местном рынке бумаги, типографских материалов и оборудования.

В общем во второй половине 1918 г. торговля в Новониколаевске набирала обороты и стала самым, если не единственным, выгодным делом. Для новониколаевского рынка были характерны: резкое увеличение количества субъектов торговли, приоритет мелкотоварности перед крупнооптовыми сделками, широкий ассортимент продовольствия, привычный дефицит привозных продуктов и промышленных товаров, а также колебания цен, редко выходившие за пределы 20-30 \%, с общей тенденцией к росту.

Новый, 1919 год Новониколаевск встретил, находясь в глубоком тылу в подчинении антибольшевистскому Российскому правительству адмирала А.В. Колчака. Правительство продолжало политику свободы торговли, поддерживало ее мероприятиями по включению коммерческих товаров в планы государственных железнодорожных перевозок и прямым финансированием отдельных операций.

В таких условиях частнопредпринимательская сфера Новониколаевска продолжала экстенсивно расширяться. В 1919 г. в городе учреждались новые фирмы, торговые товарищества и акционерные общества, открывались представительства зарубежных фирм ${ }^{19}$. Средняя и мелкая торговля уже не умещалась на базарах, в торговых корпусах, лавках и

\footnotetext{
${ }^{17}$ См.: Государственный архив Новосибирской области (ГАНО). Ф. Р-1328. Оп. 1. Д. 243. Л. 2.; Народная Сибирь. 1918. 12 июля, 3 августа, 4 сентября, 16 ноября, 27 и 28 декабря; Русская речь. 1918. 7, 27 декабря.

${ }^{18}$ Народная Сибирь. 1918. 28 июня, 21 июля, 19 ноября.

${ }^{19}$ ГАНО. Ф. Д-97. Оп. 1. Д. 330. Л. 23, 93, 109, 110; Русская речь. 1919. 20 апреля.
} 
магазинах. Новониколаевская городская управа вынуждена была официально напомнить населению про запрет торговать вне специально отведенных для этого мест, но вскоре признала бесполезность ограничений и ввела налог на торговлю с возов на всех улицах и площадях ${ }^{20}$.

Такой предпринимательский бум носил кризисный характер, так как армия торговцев пополнялась за счет массы людей, оказавшихся без работы и средств к существованию. Стиралась специализация торговли. Большинство продавцов торговали «всяким дозволенным и недозволенным товаром», который удавалось заполучить.

На рынке Новониколаевска предлагался широкий ассортимент товаров. Вот как описывает обстановку одна из местных газет: «По утрам [базарная] площадь запружена съезжающими крестьянами. Товаров “чего только нету”. [...] Сахар, зубной порошок, керосин, водка, табак, драгоценные украшения, ткани и прочее и прочее. Не говоря уже о масле, мясе, хлебе и т.п.» 21 . Вот весьма показательный фрагмент газетной рекламы кооперативной лавки Союза квартиронанимателей, которая располагалась на базаре: «В продаже мануфактура (сукно, трико, бумажные платки и др.), галантерея (пуговицы, нитки, чулки, носки, перчатки, гребенки и проч.), колониальные товары (рис, пшено, горох, манка, солод, черемуха, соль, перец и др.). Чай, кофе, варенье, патока, конфеты, орехи, балык, икра. Щетки половые, сапожные, крем, кошма, обувь, мыло, синька и др. Товары постоянно пополняются и принимаются на комиссию за минимальное вознаграждение» ${ }^{22}$.

По сравнению с 1918 г. увеличилось разнообразие продовольствия. С середины января в Новониколаевске началась продажа казенной водки. На протяжении зимы - весны 1919 г. город был необычно богат на кондитерские изделия. Магазин Н.М. Кетова, например, продавал карамель, мармелад и монпансье. Возобновила работу кондитерская С.Е. Афанасьева, предлагавшая населению громадный выбор печенья, пирожных, сахарного варенья, ревельского хлеба и белых польских батонов, выпеченных из свежих доброкачественных продуктов. В то же время перестал быть редким товаром чай, который сотнями вагонов стали завозить в Сибирь товарищество «Караван», Дальневосточное товарищество, Всероссийский союз потребительских обществ, Закупсбыт, фирмы Высоцкого и Швецова ${ }^{23}$.

Торговля промышленными товарами в Новониколаевске в начале 1919 г. также расширилась. «Китайские спички наводнили рынок», кооперативное общество «Экономия» начало продавать мануфактуру всем желающим, частники рекламировали оптовую и розничную продажу чулок, шарфов, костюмных тканей, иголок, ниток, карандашей и других привозных товаров $^{24}$. Однако в отличие от продовольственных продуктов существенно снизить дефицит промышленных товаров не удавалось. По оценке статистического отдела городской управы, населению Новониколаевска в 1919 г. «в первую очередь нужны были кожа, обувь, керосин, свечи, спички, бумага, канцелярия, стекло». За ними следовали мануфактура и галантерея, причем о готовой одежде как о массовом товаре речь даже не шла. К крайне необходимым для города товарам статистики отнесли также металлические изделия, арматуру для электрического освещения, сельскохозяйственные орудия и продукты химического производства ${ }^{25}$.

Благоприятная для торговли ситуация начала меняться весной 1919 г. В марте была объявлена реквизиция белья для военного ведомства. В Новониколаевске она продолжалась до середины мая, причем ни в коем случае не допускалась замена комплектов белья деньгами ${ }^{26}$. Похожая ситуация стала постепенно складываться с бытовыми товарами. Их не реквизировали напрямую, но Новониколаевский комитет помощи армии организовал

\footnotetext{
${ }^{20}$ ГАНО. Ф. Д-97. Оп. 1. Д. 327. Л. 264; Русская речь. 1919. 5 марта.

${ }^{21}$ Народная Сибирь. 1919. 11 февраля.

${ }^{22}$ Там же. 21 февраля.

${ }^{23}$ Русская речь. 1918. 29 декабря; 1919. 1 февраля; Народная Сибирь. 1919. 22 января; Родная Сибирь. 1919.27 февраля.

${ }^{24}$ См., напр.: Русская речь. 1919. 26 января.

25 Тм же. 17 января.

${ }^{26}$ Там же. 15, 16 мая.
} 
добровольно-принудительный сбор на оборудование новых казарм для военного гарнизона ${ }^{27}$. Военные власти стали широко пользоваться правом реквизиции и мобилизовали для своих нужд швейные, шорные и обувные мастерские и кузницы, осуществляли «обязательные приемки» телег ${ }^{28}$.

Ударом для торговли стала начавшаяся в апреле денежная реформа Российского правительства, состоявшая в изъятии из обращения «керенок». Конфискационный обмен и неспособность власти насытить рынок новыми деньгами привели $\mathrm{K}$ разрушению финансового рынка и резкому обеднению населения ${ }^{29}$.

Летом 1919 г. вооруженные силы Российского правительства отступили с Урала. Сибирь лишилась крупного рынка сбыта продовольственной продукции и источника промышленных товаров. В масштабах Сибири стали отчетливо просматриваться истощение ресурсов, бестоварье и депрессия товарооборота ${ }^{30}$.

Непосредственно для Новониколаевска изменения военно-политических условий на фронте и в тылу крайне негативно сказались уже в августе 1919 г., когда город оказался переполнен войсками, больными и ранеными военнослужащими и гражданскими беженцами. С одной стороны, здесь произошло скопление сибирских, дальневосточных и импортных товаров, с другой - эвакуированных с Урала предприятий и грузов. Это увеличивало емкость городского рынка и усилило его диспропорции, т.к. большая часть покупателей была неплатежеспособна. Дефицитные продукты, товары первой необходимости и торговые помещения, требовавшиеся для армии, изымались из рыночных отношений путем реквизиций и мобилизаций ${ }^{31}$.

Субъекты новониколаевской торговли в этих условиях изменились незначительно. В августе - сентябре 1919 г. в газете «Русская речь» увеличилось предложение мелкой коммерческой недвижимости и количество сообщений о распродажах отдельных партий товаров «в связи с отъездом». Однако фельетонист той же газеты верно подметил, что бежать большинству населения было некуда, а торговля оставалась самым доступным и выгодным делом.

Ассортимент товаров на рынке во второй половине 1919 г. также менялся мало. Но в августе акцизное управление прекратило продажу водки, из продажи почти исчезли сахар и бумага. Зато в сентябре появились американский керосин и качественные папиросы.

Цены в Новониколаевске на протяжении 1919 г. изменялись следующим образом. Стоимость минимальной продуктовой корзины в январе составила 160,35 руб., в феврале 165,6 руб., в марте - 182,0 руб., в апреле - 199,9 руб. С апреля по май произошел резкий скачок, связанный с конфискационной денежной реформой, и в мае продуктовая корзина стоила уже 261,95 руб. Затем рост цен ненадолго замедлился: в июне корзина стоила 268,06 руб., в июле - 316,26 руб. В августе из-за скопления в городе товаров она подешевела до 288,78 руб. В сентябре ее цена скакнула с новой силой к отметке в 419,29 руб. ${ }^{32}$ В октябре и ноябре стоимость скачкообразно увеличивалась по меньшей мере на 68,7 руб. и 82,6 руб. ${ }^{33}$ В результате с января по ноябрь 1919 г. минимальный месячный набор продуктов в Новониколаевске подорожал не менее, чем в 3,5 раза.

Динамика цен на продукты местного производства разнилась. Пуд пшеничной сеянки в январе стоил 30,0 руб., в апреле - 42,5 руб., в мае - 65,0 руб. Летом цена на него колебалась

\footnotetext{
${ }^{27}$ Русская речь. 1919. 24 мая, 12, 13, 15, 21, 25, 28 июня.

${ }^{28}$ См.: ГАНО. Ф. Д-97. Оп. 1. Д. 277. Л. 102-102 об.; Русская речь. 1919. 21 июня, 15 июля; Известия и труды союза сибирских кооперативных союзов Закупсбыт. 1919. № 14. С. 10-15; и др.

${ }^{29}$ Рынков В.М. Финансовая политика антибольшевистских правительств... С. 154.

${ }^{30}$ Гинс Г.К. Сибирь, союзники и Колчак. Поворотный момент русской истории. 1918-1920. (Впечатления и мысли члена омского правительства). М., 2007. С. 418-419.

${ }^{31}$ См.: Русская речь. 1919. 7, 8, 14, 16, 17, 19, 21 и 22 августа.

${ }^{32}$ Сост. по: ГАНО. Ф. Д-146. Оп. 1. Д. 420. Л. 63-64; Там же. Д. 422. Л. 106-107 об.,128; Вестник Закупсбыта. 1919, № 1/2. С. 36-41, № 5. С. 36-43; Русская речь. 1918. 6 мая, 18 июня; Сизов С.Г. Белая столица России... C. 41.

${ }^{33}$ См.: Вестник Закупсбыта. 1919. № 21. С. 34-42; № 23. С. 36-41.
} 
между 65 и 75 руб., а осенью ухудшение военно-политической обстановки совпало с сезонным удорожанием, и стоимость сеянки достигла в ноябре рекордной величины в 160 руб. Цены на говядину в январе держались на уровне 62 руб. за пуд, но затем муниципальные поставки, удерживавшие цену, прекратились из-за отмены масляной монополии, и стоимость мяса стала расти наравне с другими продуктами: в апреле - 95 руб., в мае 200 руб., в июне - 160 руб., в августе - 150 руб. и в ноябре - 350 руб. Меньше всего увеличились цены на картофель: с январских 8 руб. за пуд до ноябрьских 35 руб. Паточные заводы из-за сомнительности продукции закрылись как нерентабельные, а потребительский спрос на картофель в значительной мере обеспечивали личные огороды жителей города и окрестностей ${ }^{34}$.

Цены на привозные товары первоочередного значения пыталось сдерживать акцизное управление. Сахар в январе стоил 16,26 руб. за фунт, в апреле - 19,5 руб., в июле - 49,5 руб., в августе - 23,5 руб., в сентябре - 28,0 руб., в октябре 27,5 руб., а в ноябре - 55,0 руб. При этом постановление о продаже сахара не выше акцизных цен лишало рынок этого товара. Его стали продавать «из-под полы по самым диким ценам» ${ }^{35}$. Чайный рынок в отличие от сахарного оказался хорошо наполнен товаром, а потому цены на него колебались меньше. Фунт байхового чая дорожал и дешевел в диапазоне от 35 до 60 руб.

Изменение цен в сегменте непродовольственных товаров отследить сложнее. Погонная сажень березовых дров на новониколаевском базаре в январе 1919 г. стоила 200-225 руб., в конце марта - 260-280 руб., а в начале мая - 480-500 руб. К августу их стоимость как минимум удвоилась и составляла от 600 до 840 руб. за погонную сажень. В декабре дрова стоили около тысячи рублей за один воз (приблизительно четверть погонной сажени) ${ }^{36}$.

Новониколаевские ежедневные газеты в январе - июне 1919 г. подорожали постепенно с 40 коп. до 75 коп. за номер. Из-за августовского обострения дефицита бумаги цена одного номера газеты повышалась трижды и к началу сентября составила 1,5 руб. В октябре все городские издания начали получать бумагу через военно-пропагандистское ведомство, присвоившее все местные запасы. Поэтому в октябре и ноябре розничная цена газет оставалась неизменной - 2 руб. за номер.

В общем динамика изменения цен на товары в Новониколаевске с января по апрель 1919 г. выглядела как плавная повышающаяся кривая, продолжая тенденцию второй половины 1918 г. В мае начались скачкообразные повышения цен на большинство товаров.

В середине ноября 1919 г. Новониколаевск оказался в прифронтовой полосе. Отступавшие из Омска антибольшевистские вооруженные силы предполагали организовать здесь оборонительный рубеж. С 19 ноября до 4 декабря город являлся резиденцией Верховного правителя и Верховного главнокомандующего адмирала А.В. Колчака. Концентрация войск в Новониколаевске, загромождение всех транспортных путей, реквизиции помещений и товаров, мобилизации населения и деятельность контрразведки стесняли торговлю ${ }^{37}$. При этом ожидания покупателей, которые перед приходом Советской власти намеревались запастись продуктами, и продавцов, стремившихся сбыть товары, подхлестывали рынок. В таких условиях крупные торговцы не могли вести операции. Деятельность Закупсбыта оказалась в декабре полностью парализована по политическим причинам. Мелкотоварный рынок в ожидании военных действий продолжал жить, но менее насыщенной жизнью, чем раньше. В последнем номере «Русской речи» от 12 декабря 1919 г. было напечатано всего три больших коммерческих объявления, попавшие в него из-за заранее выкупленного рекламного места, и только два частных предложения купить кошеву и мебель.

\footnotetext{
${ }^{34}$ См.: ГАНО. Ф. Д-146. Оп. 1. Д. 420. Л. 63-64; Там же. Д. 422. Л. 106-107 об.,128; Вестник Закупсбыта. 1919. № 1/2. С. 36-41, № 5. С. 36-43; № 6. С. 34-43; № 10. С. 30-37; № 14/15. С. 28-34; № 19. С. 26-34; № 21. С. 34-42; № 23. С. 36-41; Русская речь. 1918. 6 мая, 18 июня.

${ }^{35}$ Русская речь. 1919. 23 февраля.

${ }^{36}$ См.: Русская речь. 1919. 15 января, 26 марта, 6 мая; ГАНО. Ф. Д-146. Оп. 1. Д. 420. Л. 72; Шиловский М.В. Новониколаевск осенью - зимой 1919 года // Гражданская война на востоке России (ноябрь 1917 - декабрь 1922 г.): сб. мат-лов. Всерос. науч. конф. Новосибирск, 2019. С. 234.

${ }^{37}$ См.: Вестник Закупсбыта. 1920. № 1. С. 42.
} 
Таким образом, динамика товарного рынка Новониколаевска на протяжении Гражданской войны прошла сложную траекторию. На свержение Советской власти в конце мая 1918 г. рынок отреагировал стремительным восстановлением торговой сферы. Затем по мере расширения территории, подконтрольной антибольшевистским правительствам, поддерживавшим свободу торговли, на новониколаевском товарном рынке увеличивалось количество продавцов, рос ассортимент товаров и спрос на них. Экстенсивное развитие новониколаевского рынка происходило в основном за счет мелкой частной торговли продовольствием, переориентации крупных товарно-денежных операций на уральский, дальневосточный и зарубежные рынки, а также за счет почти двукратного роста населения города. Весной 1919 г. условия для ведения торговли начали ухудшаться. Государственная власть, обеспечивая возраставшие военные нужды и пытаясь смягчать экономические потери населения, стала вмешиваться в рыночные отношения. С марта товарно-денежные отношения в Новониколаевске функционировали в режиме адаптации к возраставшему давлению военного ведомства и удару неудачной денежной реформы. Количество субъектов торговли стало избыточным, в ассортименте товаров нарастали диспропорции между широким предложением продовольствия и дефицитом промышленных изделий. Относительно плавный рост цен сменился их скачкообразной динамикой. Отступление вооруженных сил Российского правительства с Урала принесло рынку Новониколаевска кратковременный эффект в виде насыщения товарами и снижения стоимости продовольствия в августе, но затем товарно-денежные отношения стали терять остатки пропорции между спросом и предложением. Фронтовые условия второй половины ноября первой половины декабря 1919 г. еще больше стеснили торговлю, которая стала схлопываться до мелкотоварных форм.

\section{Лumepamypa}

Временное Сибирское правительство (26 мая - 3 ноября 1918 г.): сб. док-тов и мат-лов / сост., отв. ред. В.И. Шишкин. Новосибирск: СОВА, 2007. 818 с.

Западно-Сибирский комиссариат Временного Сибирского правительства (26 мая - 30 июня 1918 г.): сб. док-тов и мат-лов / сост., науч. ред. В.И. Шишкин. Новосибирск: Новосибирский государственный университет, 2005. 246 с.

Кокоулин В.Г. Повседневная жизнь горожан Сибири в военно-революционные годы. Новосибирск: Тип. Офсет, 2013. 385 с.

Косякова Е.И. Из истории городской повседневности Новониколаевска-Новосибирска (1893-1941 гг.): роль поставок продовольствия из окрестных деревень в питании горожан // Труды Новосибирского государственного аграрного университета. Экономика. Проблемы сельского хозяйства России. Новосибирск: Изд-во НГАУ, 2004. С. 246-259.

Рынков В.М. Финансовая политика антибольшевистских правительств востока России (вторая половина 1918 - начало 1920 г.). Новосибирск: РИЦ НГУ, 2006. 212 с.

Рынков В.М. Продовольственный рынок Сибири во второй половине 1918-1919 гг.: пространственные и отраслевые модели // Исторические вызовы и экономическое развитие России: мат-лы Всерос. науч. конф. с междунар. уч. Екатеринбург: Альфа Принт, 2019. С. 461-466.

Сизов С.Г. Белая столица России: повседневная жизнь Омска (июнь 1918 - ноябрь 1919 г.). Омск: СибАДИ, 2018. 240 с.

Совет министров Российского правительства: журналы заседаний (18 ноября 1918 3 ноября 1920 г.): с док-тов / сост. и науч. ред. В.И. Шишкин. Новосибирск: Изд-во СО РАН, 2016. T. 1.748 с.

Черных Г.И. Торговля в Новосибирске // Новосибирск. Энциклопедия. Новосибирск: Новосиб. кн. изд-во, 2003. С. 879-880.

Шиловский М.В. Новониколаевск осенью - зимой 1919 года // Гражданская война на востоке России (ноябрь 1917 - декабрь 1922 г.): сб. мат. Всерос. науч. конф. с междунар. уч. / отв. ред. В.И. Шишкин. Новосибирск: Изд-во СО РАН, 2019. С. 233-242. 


\section{References}

Chernykh, G.I. (2003). Torgovlya v Novosibirske [Trade in Novosibirsk]. In Novosibirsk. Entsiklopediya. Novosibirsk, pp. 879-880.

Kokoulin, V.G. (2013). Povsednevnaya zhizn gorozhan Sibiri v voenno-revolutsionnye gody [Everyday Life of the Townspeople of Siberia in the Military-Revolutionary Years]. Novosibirsk. $385 \mathrm{p}$.

Kosyakova, E.I. (2004). Iz istorii gorodskoy povsednevnosti Novonikolaevska-Novosibirska (1893-1941 gg.): rol postavok prodovolstviya iz okrestnykh dereven v pitanii gorozhan [From the History of Urban Everyday Life of Novonikolaevsk-Novosibirsk (1893-1941): the Role of Food Supplies from the Surrounding Villages in the Nutrition of the Townspeople]. In Trudy Novosibirskogo gosudarstvennogo agrarnogo universiteta. Ekonomika. Problemy selskogo khozyaystva Rossii. Novosibirsk, pp. 246-259.

Rynkov, V.M. (2006). Finansovaya politika antibolshevistskikh pravitelstv vostoka Rossii (vtoraya polovina 1918 - nachalo 1920) [Financial Policy of Anti-Bolshevik Governments in Eeastern Russia (Second Half of 1918 - Early 1920)]. Novosibirsk. 212 p.

Rynkov, V.M. (2019). Prodovolstvennyy rynok Sibiri vo vtoroy polovine 1918-1919: prostranstvennye i otraslevye modeli [Siberian Food Market in the Second Half of 1918-1919: Sspatial and Sectoral Models]. In Istoricheskie vyzovy i ekonomicheskoe razvitie Rossii. Yekaterinburg. 2019, pp. 461-466.

Shilovskiy, M.V. (2019). Novonikolaevsk osenyu - zimoy 1919 [Novonikolaevsk in Autumn Winter 1919]. In Grazhdanskaya voyna na vostoke Rossii (noyabr 1917 - dekabr 1922). Novosibirsk, pp. 233-242.

Shishkin, V.I. (Ed.). (2005). Zapadno-Sibirskiy komissariat Vremennogo Sibirskogo pravitelstva (26 maya - 30 iyunya 1918) [West Siberian Commissariat of the Provisional Siberian Government (May 26 - June 30, 1918)]. Novosibirsk. 246 p.

Shishkin, V.I. (Comp., Ed.). (2007). Vremennoe Sibirskoe pravitelstvo (26 maya - 3 noyabrya 1918) [Provisional Siberian Government (May 26 - November 3, 1918)]. Novosibirsk. 818 p.

Shishkin, V.I. (Comp., Ed.). (2016). Sovet ministrov Rossiyskogo pravitelstva: zhurnaly zasedaniy (18 noyabrya 1918 - 3 noyabrya 1920) [Council of Ministers of the Russian Government: Meeting Journals (November 18, 1918 - November 3, 1920)]. Novosibirsk. Vol. 1. 748 p.

Sizov, S.G. (2018). Belaya stolitsa Rossii: povsednevnaya zhizn Omska (iyun 1918 - noyabr 1919) [White Capital of Russia: Everyday Life of Omsk (June 1918 - November 1919)]. Omsk. $240 \mathrm{p}$.

Статья поступила в редакцию 17.06.2021 г. 